\title{
Nationalism, Democratisation and Primordial Sentiment in Indonesia: Problems of Ethnicity versus Indonesian- ness (the cases of Aceh, Riau, Papua and Bali) ${ }^{1}$
}

\author{
Irine Hiraswari Gayatri \\ Center for Political Studies \\ Indonesian Institute of Sciences
}

\section{Background}

Indonesia has been dealing with ethnicity issues since the early days of independence. A local uprising in 1950 in South Maluku, initiated by Republik Maluku Selatan, is evidence of an early serious attempt at separatism on behalf of a particular ethnic group in the new republic. Since then in this multi-ethnic state that is Indonesia, there has been no reduction in efforts or movements that promote ethnic identity. This continuing situation perhaps supports Ernst Geller's contention that there is a big possibility that a strong primordialist sentiment will continue in a post-colonial society. The disproportionate ethnic representation in the central government is assumed to be the trigger in encouraging primordialist or ethnic sentiments, which were best reflected in the Java versus non-Java debate at the time that Geertz (1973: 273-277) wrote, that is, the 1970s. There are other contributing factors to primordialist sentiment, for instance; economic disadvantage, ideological confrontation or the interests of local elites.

The historical progress of this nation shows the rise of ethnic-based movements in Aceh, Riau, West Java, the North Celebes, the Moluccas,

1 This paper is a résumé of a series of research projects in 2008 on nationalism, identity and ethnicity after the fall of the Soeharto regime. The research team from the Center for Political Studies, Indonesian Institute of Sciences, comprised Firman Noor, Syafuan Rozi, Irine Hiraswari Gayatri, Muridan S Widjojo and Mochtar Pabottingi. 
Bali and Papua, which, in one way or another, have challenged the concept of Indonesian-ness up to the end of the Old Order (Orde Lama or the Soekarno regime). During the New Order period, with strong support from the military, the government suppressed any attempt inspired by ethnic sentiment that could cause social or political fissures. As the central government's economic and political modernisation programmes progressed, which tended to produce uniformity and to reduce the influence of ideology, any matters that had attributes the government considered would lead to disharmony or unrest (including ethnic unrest) were not allowed to see the light of day. The government took strong measures to counter any opinions and actions that might be seen to be against the state's official interpretation of 'nationhood'. Under these conditions, primordialist sentiments tended to atrophy. In general, the New Order was seen as having been successful in reconstructing the political, economic and social infrastructures and this success in many ways mitigated disappointment with other government actions and it also reduced the potential for ethnic dissatisfaction. Nonetheless, the New Order's pembangunan (development) programmes did not eliminate ethnicity concerns. The main cause of the rise in support for ethnic sentiments during the New Order was not solely ideological nor was it political (for example, the ethnically disproportionate filling of public or government positions), but it was more to do with economic disadvantage and the unregulated exploitation of natural resources that brought no benefits to the local people and over which they had little control. ${ }^{2}$ These last two reasons have frequently been the tipping point for radicalising ethnic groups that regard themselves as victims of the treatment from the majority or the central government. This dominant control by the central government, unfortunately, was followed by cultural hegemony and cultural uniformity that marginalised particular ethnic identities. This situation was also complicated by the application of authoritarian and repressive measures by the central government, which, specifically, caused the crystallisation of ethnicity — within limits they led to a collective resentment - but also, in general, they caused distortions in the construction of a united nation (Pabottingi, 2000).

2 According to Burhan D Magenda (1990), the New Order was supposed to be able to settle those issues. 
The Reform era (Reformasi) has been marked by democratisation and provides a glimmer of hope that the many ethnic groups in Indonesia will be acknowledged and their differences appreciated. The move to regional autonomy has caused the central government to devolve authority to local or regional governments, which allows those governments more scope for policy making at their local level but also gives them some influence over central government policies. Later developments in the trend to devolve authority to the regions led to increased concessions from the central government. Aceh and Papua were granted special autonomy status in response to demands, among others, for more equitable central-regional financial arrangements; the Regional Representatives Council (DPP) was established in the national legislature though it does not have legislative functions; and local political parties are allowed to contest elections, first in Aceh and later in other areas such as the coal district in North Sumatra and in Rote Ndao (NTT). Until Aceh demanded and was given the right to have its own political parties, the only parties allowed by the central government were national, such as Golkar or the PKB (National Awakening Party) to name two and they were subject to control from Jakarta.

To give a theoretical framework to the research, the research team assumed a working hypothesis that a link between democratisation and ethnic revival is highly likely. There are pros and cons to this connection: on the one hand it allows opportunities to strengthen democracy: on the other hand, it allows the strengthening an exclusive identification with keetnisan (ethnicity), which is not a step in the direction of national unity. It would seem that democratisation in Indonesia has a paradox at its heart. One observer, Baladas Ghoshal (2004), said that in the context of Indonesia '...the removal of the lid on politics has opened up a Pandora's box, fomented ethnic and religious conflicts, and even encouraged regional separatism, thereby creating political and economic uncertainties...' Democratisation can provide an arena for the rise of anti-immigrant prejudice (for instance in Bali it is resented that there are Javanese meatballs in Klungkung and Bali meatballs elsewhere) but it can also provide a way of channelling the aspirations of local ethnic groups, separatist or not, by giving them the means to engage 
politically, whether it be an election for a regional head or a legislative election (as in Papua, where provinces and districts were expanded and followed by local elections in which Papuans participated. By creating new regions, some actors and sympathisers of the Papuan Morning Star movement will become members of the new elite.

Along with the development of democratisation, the traditions of ethnicity still remain as a reality at the heart of the Indonesian nation. The impression is that the weaker central government is in the Reform era, and the more accommodating and inclusive it is, these are circumstances that will lead to ethnic revival recovering its momentum. Generally, evidence for this ethnic revival is the perceived increase in the use of ethnic terminology or jargon, such as bumiputra (sons of the soil or indigenous Indonesians); the more extensive use of local languages; and the series of efforts on behalf of governments to set up separate territories or regions based on ethnicity; and the widespread public discourse in some areas, such as in Riau and Bali, to establish independence. In regions such as Aceh and Papua these changes have led to increased efforts by separatist movements, although perhaps on the surface the level of intensity has started to decline.

There are various statements made and expressions used by some ethnic groups that are a form of self-affirmation of their group existence and at the same time, within limits, are a reflection of their opposition to the concept of a national, shared destiny and show a reduced commitment to future ideals as a nation. This shows that the phenomenon of ethnic sentiment, which can lead to total independence or to separatism is not something that can be ignored in the efforts to encourage Indonesianness and nation building.

In this context, the emergence of separatist movements in Aceh is an expression of rejection of keindonesiaan (Indonesian identity). The spread and strengthening of keindonesiaan in the Veranda of Mecca (a metonym for Aceh) is seen instead by some of the people of Aceh as a process of Javanisation or even secularisation. The process of 'cultural hegemony' through the manipulation of violence and coercion was, unfortunately, also followed by unfair central government economic 
policies. The central government not only ignored the cultural aspirations to implement Islamic Law but also imposed major projects in Aceh as cash cows where the profits went to the central government. As a result, most Acehnese lived in poverty. Their disadvantaged position raised awareness that their political, economic and social entitlements were being bypassed. Thus the Acehnese rebelled, which started with the special request by David Beureueh to Soekarno in the 1950s and lasted until the Hasan di Tiro movement in 1976. The government curbed the separatist movement that emerged later in Aceh by the promulgation of a Military Operation Area (DOM) and imposing martial law. However, within limits, it reinforced the emergence of an increasingly ethnic sentiment in Aceh.

Meanwhile, as in Aceh, a strengthening of ethnic sentiment also appeared widely in Papua. In fact, this awareness has been manifested in attempts to secede from Indonesia. For some people of Papua, the option for independence is a goal that is not negotiable. In the case of Papua, Edward Aspinall and MT Berger believe that internal factors, the way the Soeharto government treated the Papuans, and external factors, such as international perceptions of the existence of minority groups within a country, played an important role. Aspinall and Berger (2001: 139-169) believe that the extensive use of coercion and violence by the central government, particularly during the New Order era, indeed contributed to the strengthening of a local ethnic sentiment.

External factors, mainly after the collapse of the Communist world, gave encouragement to the flourishing separatist movements, and especially increased the tendency of large countries to give more consideration to the rights of their indigenous communities. Some lessons can be drawn from the perspective presented by Aspinall and Berger, that promoting nationalism by using heavy-handed military measures is clearly is not a clever step in maintaining the integrity of the nation and in restoring national self-confidence as can be witnessed in Papua and Aceh. Meanwhile, JA Denny's (2003) analysis showed that economic inequality, ethnic particularity, historicity and exploitation of natural resources played major roles in strengthening the Papuan community's 
aspirations for independence. Ethnic distinctiveness is something that really distinguishes the Papuans from the Indonesian community in the Western hemisphere but Denny's assertion that the rise of ethnic sentiment, which in the term's extended meaning is associated with repressed longings or desires in term's extended meaning, not only in economic and political contexts and also in matters of ethnic identity, is something that can not be ignored. Meanwhile, a possible reason why Riau has not rebelled is that their ethnic traditions are not too strong, at least, if compared with Papua and Aceh.

In line with developments in the two provinces mentioned above, structural problems, especially economic disadvantage played an important role in awakening Riau people about their identity. Protracted poverty, ascribed to mismanagement by past governments, became the main reason a 'Riau-ness' sentiment developed, which was backed by several prominent local intellectuals and youth, even by some who had been keen supporters of the New Order government. Riau ethnic sentiment was later shown by the emergence of a Riau Merdeka discourse, which, until recently, was still consistently supported. As it developed, supporters divided into several groups; the moderates and radicals who stressed the spirit of independence, and those who insisted on Riau independence in the context of territoriality. ${ }^{3}$ The Riau case has tended to be seen as being without precedent. However, there is nothing new about issues such as nationalism and the revival of ethnicity. Taking, as an example, the conflict between the ethnic majority Sinhalese and the minority Tamil groups in Sri Lanka shows how a bloody ethnic conflict can occur in a country without historical precedents for such a damaging dispute.

3 Petikan Deklarasi Riau Merdeka. Sudah lebih setengah abad kami menggantungkan hidup pada republik ini, selama itu pula minyak kami dijarah. Tak setitik pun menetes di tanah kami. Sungai dan tanah kami tak lagi memberi hidup karena polusi. Sudah lebih dari seperempat abad tanah kami dijarah sebagai konspirasi pusat dan konglomerat. Maka hari ini, kami putuskan untuk menentukan nasib kami sendiri. Kami telah mulai menukilkan sejarah kami dalam lembaran yang baru akan hak-hak kami, identitas dan tradisi kami dengan jalan damai. We are beginning to think, we are writing a new chapter of history to demand our right[s], take on our duties, and defend our identity and our tradition, with peace. Pekanbaru, 15 March 1999. 
The emergence of a Bali Merdeka discourse just after the start of the Reform era was surprising. As time went on, the Balinese people saw the public discourse more as a strengthening of the Ajeg Bali concept. This concept and its public discussion and acceptance were a consequence of social and economic changes in Bali over which the people felt they had little control. These changes stem from the massive influx of capital that largely ignored indigenous rights and environmental carrying capacity. One theme of the Ajeg Bali discussion was to urge the Balinese people to consider the meaning of Bali-ness and to strengthen the ethnic independence of the Land of the Gods. The Ajeg Bali idea can be interpreted as an attempt to reconstruct Balinese identity based on tradition, culture and religion. According to I Nyoman Dharma Putra (2003), within its comprehensive expression, Ajeg Bali illustrates a strong desire for the cultural and political independence, within limits, of the Balinese. In another sense, Ajeg Bali as a concept reflects to a much greater extent than at present the resentment and rejection of efforts by the central government to dictate policies to the locals, policies that are felt not to be in line with the values of the Balinese. In addition to the discourse around Ajeg Bali and Jagadita at the paradigmatic level and in the actual movement, local government policies have been transparently and extensively based on Balinese values. Although there was a Bali Merdeka movement that protested against a ministerial declaration and waves of mass protests against the central government's Pornography Bill, generally it is difficult to imagine 'armed movements' in Bali or ones that are similar to Gerakan Aceh Merdeka (Free Aceh Movement) or Organisasi Papua Merdeka (Free Papua Movement), at least for the next few years. But it seems that identity politics is coming to the forefront in Bali today.

In this study, the researchers have come to understand that ethnic boundaries can change over time to cover, reduce or amalgamate the various subethnic groups that might exist in some areas and periods. This is especially so when there is a collective interest prompted by insecurity because of the pattern of relations with other parties. In other words, awareness of a group's ethnicity emerges within the scope of more general, unspecified circumstances after an interaction with other communities, in a capacity 
as a majority or a minority group. In this case, as Amartya Sen (2007) mentioned, there will appear another dimension of ethnic awareness in the form of defining 'us' and 'them' that can be illusory, subjective and often irrational. Ethnicity in Aceh, Papua, Bali and Riau is a phenomenon that has emerged in the midst of weakening central state control. There is no single factor that will explain why the ethnic consciousness has risen. Among other factors in its rise are the emerging pseudo-political representation, economic inequality, or artificial promotion of a particular local culture, which all to some extent contributed to the strengthening of identity in Bali, Aceh, Papua and Riau. Meanwhile democratisation possibly works as a catalyst for the emergence of ethnic sentiments. However, this needs to be tested further. Against this background, the extent to which ethnicity increases and becomes a threat to national identity is an interesting topic that needs more research. It is possible that the emergence of ethnic sentiment is a natural consequence in a state where democracy is advancing without it necessarily turning into threat to the nation. The central question of this study is to reveal to what extent ethnic sentiment and ethnic identity has strengthened in some areas in Indonesia that are currently experiencing democratisation and political openness. How does it affect Indonesian-ness?

\section{Theoretical Overview on the Emergence of Ethnic Sentiments}

In the context of emerging nation-states, Geertz (Geertz, c1973: 269277) believes that the opportunities for strengthening ethnic sentiment remains largely in line with the strengthening of primordial sentiments. This is related to the participation of all elements of society into a new country. However, later in development, several factors contribute to the rise of ethnic sentiment. This is particularly relevant if the government that replaced the colonial rulers deliberately creates policies that are disadvantageous to one or more ethnic groups or that differentiates between groups.

Joseph Rothschild (2007: 29), writing on the resurgence of ethnic sentiment, noted two reasons an ethnic group that originally intended 
to be part of a nation later loses its nationalist orientation. First, because there is inequality or discrimination in the fields of politics, the economy, society and culture, which contributes to the strengthening of the identity of an ethnic group. Second, the influence of an leader who is able to mobilise members of a particular ethnic group so that it has an ethnic awareness that later will lead to the formation of an independent nation.

The first reason mentioned above is the essence of an approach, known as the contextual approach, to understanding nationalism. The contextual approach is based on the premise that an increasing ethnic sentiment is associated with injustice in various fields; economic, political, social and cultural, that is faced by an ethnic group, whether through neglect, exploitation, domination, repression or discrimination (Rothschild, 2007:29). There are three theoretical standpoints in attempting to explain injustice (Rothschild, 2007: 5-7). The first theory is called 'revised modernisation', which explains that changes in resource distribution, urbanisation and industrialisation in a country encourage increased competition among community members. In this competition, the group that has little capital, education or skills will be eliminated. This group will later feel alienated and no longer feel as able to continue to identify with the current political system. To compensate, the excluded group looks for a new identification with reference to other symbols, where the nearest, most familiar and easiest to be found is ethnic identity.

The second theory is the theory of internal colonisation. According to this theory, the injustice causes the losers, the excluded group, to determine to break away from the current state structure. This is caused by the feelings of inferiority by an ethnic group that regards itself as a victim of oppression and exploitation by the current system of government or by other ethnic groups.

The third theory is the relative deprivation theory developed by Ted Robert Gurr (2005), which posits that the gap between ideals and the facts leads to the rise of ethnic group frustration. Gurr stated that if the increase in an expectation is not accompanied by the capability to achieve it, it can lead to dissatisfaction, which, if politicised, will 
give birth to a social movement that will be in the direction of national disintegration (Gurr, 2005: 12-13).

In general, the contextual perspective that emphasises injustices as the main reason is enough to explain the structural factors behind the rise of ethnic sentiment. However, this perspective cannot satisfactorily explain why some groups that experience discrimination and injustice have not developed a sense of ethnicity or even nationality. It is here that the constructivist perspective finds relevance, which posits that there is social engineering by elite groups at work in exploiting ethnic sentiments and this is a second factor in explaining the rise in the spirit of ethnic identity.

According to this constructivist viewpoint, social engineering by a particular entity is the cause of the rise of ethnic sentiment. By exploiting primordial legacies, combined with the current political, economic, social and cultural environment, these engineers affect the collective memory and convince ethnic groups of ideal conditions in the future. There are two important elements in manifesting this effort; leadership as a guide in the struggle and an organisation as an agent that directs and mobilise the masses. This approach is quite capable of capturing the role of political elites in exploiting and utilising ethnic sentiments for a particular purpose. However, this approach seems to be too elitist and deterministic so that it often discounts the ability and dynamics of a society in determining its political development; even where there was a spontaneous revival of ethnic attitudes, as happened in Assam, this approach is not convincing. ${ }^{4}$

In the meantime, still associated with the causes of the rise of ethnic sentiment, David Brown (2004: 56-62) implicitly suggests that democratisation has a role. According to Brown, a political change from an authoritarian regime to democracy allows an ethnic group an opportunity to gain their identity again and then separate from the old political system. Weak transitional government structures, in addition to the emergence of diversity of interests and conflicts among new

4 See, for example, a similar point of view to this in Connor (1994: 73-74). 
political elites, can encourage the creation of chaotic conditions that lead to disintegration. However, Brown has not always been pessimistic about democratisation. According to Brown (2004) and Ghia Nodia (1998), democratisation can establish a new identity that is tolerant to ethnic communities that are neglected and able to establish a collective identity that is the ideal of citizenship identity, and that emphasises tolerance, equality and rationality.

Unlike the diverse points of view above, Jacques Bertrand (2004a), in his study of nationalism and ethnic conflict in Indonesia, looks at past Indonesian government policies and the development of the current government institutions as factors that play a role in matters of ethnicity. According to Bertrand, the repressive policies of past authoritarian regimes leave scars that cannot easily disappear and ethnic self-awareness is able to emerge when there are changes of regime or political system. Support by a regime for the benefit of a particular ethnic group or a system that is at the expense of other secondary ethnic groups will rebound to the detriment of the favoured group when there is a change of regime. On the other hand, the secondary group or groups have an opportunity to improve their positions in the political system when there is a change of regime. Meanwhile, the political institutions that have been altered with a change of regime also affect the political dynamics. These political dynamics in turn provide opportunities for some ethnic groups to be more involved in the new system. In such situation, when the circumstances are conducive, it is not impossible for an ethnic group, which feels it has been at a disadvantage to use the opportunity to break away.

\section{About this study}

From such a diversity of views it can be concluded that there are several factors leading to an ethnic revival within a nation-state. Those factors of ethnic revival in general have implicitly been addressed in the conclusions of the research team's findings in previous years. These factors include, first, the presence of a consciousness of a primordial 
unity that has particularities that are different from other public entities; second, the existence of social and economic inequality; third, the emergence of an awareness that is encouraged by leadership, by actors or by particular organisations; fourth, the opportunity opened up by democratisation and regime change; and fifth, past government policies, including the effect of governance structures and practices from the colonial administrations that are discriminatory. Thus, this research is based on the exploration of these factors and at the same time has been testing the determinants of these factors.

The author used qualitative research methods with in-depth interviews and a literature study. The interviews were in four research areas (Bali, Papua, Riau and Aceh) were with several source persons at each of the research sites. Those people who were interviewed came from various background: there were government officials, politicians, academics, community leaders, traditional leaders, activists and students, entrepreneurs, representatives from civil society organisations and the press. The resource persons were chosen for their knowledge, experience and expertise related to the topics of the research. To get comprehensive and balanced outcomes from the field research, the set of interviewees comprised those who were known publicly to be a supporter of the unity of Indonesia; those identified as critical of unity or even supporters of separatism; and those who could be viewed as neutral.

Research areas for this study are Papua, Aceh, Riau and Bali. The first three locations are regions rich in natural resources. Aceh, Riau and Papua can be treated as regions that have a similar background and similar economic characteristics. Bali is studied for the sake of comparison because it does not rely on natural resources as the core support for its economy. Second, all four regions have historical experience and folk memories of being a nation. Third, the four regions are facing problem stemming from the rise of ethnic sentiment in the Reform era and although there are similarities there are also differences. Fourth, in responding to Indonesian-ness, these four regions reacted differently one from the other, the reactions being from expressing ethnic sentiments 
in a public dialogue or discourse to initiating movements demanding justice or demanding independence.

Those factors mentioned above have been the background for our comparative fieldwork. With a variety of significant characteristics in each respective research area, we hope to understand much better the constituents of the problem. The basic achievement of the research is in understanding the phenomenon of the rise of ethnic identities in the areas and regions that have experienced it in this era of contemporary Indonesia. In the meantime, we realise that each area of study has a unique and rich cultural diversity, as well as having a variety of sub-cultures or sub-ethnic groups that cannot be easily generalised. Therefore researchers need to be more sensitive to the cultures of various communities in each region.

\section{References}

Anderson, Benedict. (1991 [1983]). Imagined communities: reflections on the origin and the spread of nationalism (2nd edition). London: Verso.

Aspinall, Edward and MT Berger. (2001). 'The Break Up of Indonesia? Nationalisms after Decolonisation and the Limits of the Nation-State in Post-Cold War Southeast Asia'. Third World Quarterly, 22 (6).

Barth, Fredrik. (1969). (ed.). Ethnic groups and boundaries: the social organization of cultural difference. Boston: Little Brown.

Bertrand, Jacques. (2004a). Nationalism and ethnic conflict in Indonesia. Cambridge: Cambridge University Press.

. (2004b). 'Democratization and Religious and Nationalist Conflict in PostSuharto Indonesia. In Susan J Henders, Democratization and identity, regimes and ethnicity in East and Southeast Asia. New York: Lexington Books.

Brown, David. (2004). 'The Democratization of National Identity'. In Susan J Henders, Democratization and identity, regimes and ethnicity in East and Southeast Asia. New York: Lexington Books.

Comarrof, JL. (1987). 'On Totemism and Ethnicity'. Ethnos, 21(3-4).

Connor, Walker. (1994). Ethnonationalism: the quest for understanding. Princeton: Princeton University Press.

Denny JA. (2003). 'Membelah Politik Papua'. SP Daily, 2 September.

Diamond, Larry and Marc F Plattner (eds). (1998). Nasionalisme, konflik etnik, dan demokrasi. Bandung: ITB.

Eriksen, Thomas Hylland. (1993). Ethnicity and nationalism. London: Pluto Press. 
Geertz, Clifford. (c1973) The interpretation of cultures: selected essays. New York: Basic Books.

Ghosal, Baladas. (2004). 'Democratic Transition and Political Development in PostSoeharto Indonesia'. Contemporary Southeast Asia, 26(3).

Gurr, Ted Robert. (2005). Why Men Rebel. Princeton: Princeton University Press.

Howoritz, Donald L. (2001). 'Structure and Strategy in Ethnic Conflict: a few steps toward synthesis'. In R William Liddle (ed.). Crafting Indonesian Democracy. Bandung: Mizan.

Magenda, Burhan D. (1990). 'Perubahan dan Kesinambungan dalam Pembelahan Masyarakat Indonesia'. Prisma, 4.

Nodia, Ghia. (1998). 'Nasionalisme dan Demokrasi'. In Diamond, Larry and Marc F Plattner (eds). Nasionalisme, konflik etnik, dan demokrasi. Bandung: Institut Teknologi Bandung.

Noor, Firman (ed.). (2007. Nasionalisme, demokratisasi dan identitas primordialisme di Indonesia,. Jakarta: Lembaga Ilmu Pengetahuan Indonesia, Pusat Penelitian Politik.

Pabottingi, Mochtar. (2000). Lima palang demokrasi satu solusi: rasionalitas dan otosentrisitas dari sisi historis-politik di Indonesia. Orasi ilmiah pengukuhan sebagai ahli peneliti utama puslitbang politik dan kewilayahan Lembaga Ilmu Pengetahuan Indonesia. Jakarta: Lembaga Ilmu Pengetahuan Indonesia, Pusat Politik dan Kewilayahan.

Putra, I Nyoman Darma. (2003). 'Bali Pasca-Bom: Konflik, Kekerasan dan Rekonstruksi Identitas Budaya Seputar "Ajeg Bali"”. Paper presented at Kongres Kebudayaan V, 19-23 October 2003, Bukittinggi, West Sumatra.

Kurniawansyah, Rudi. (2006). 'Bergulir Wacana Otonomi Khusus bagi Riau'. Media Indonesia, 5 May 2006.

Rab, Tabrani. (2005). 'Merdeka atau Bergabung Negara Lain'. In Digdo Juniarto (ed.)., Riau dalam tiga opsi: otonomi, federal atau merdeka. Pekanbaru: ISDP.

Rothschild, Joseph. (2007). Ethnopolitics: a conceptual framework. New York: Columbia University Press.

Sabhlok, Smita G. (2002). 'Nationalism and Ethnicity and the Nation-State in South Asia'. Nationalism and ethnic politics, 8 (3).

Salamone, FA and CH Swanson. (1979) 'Identity and Ethnicity: ethnic groups and interactions in a multi-ethnic society'. Ethnic groups, 2.

Schildkrout, E. (1974). 'Ethnicity and Generational Differences among Urban Immigrants'. In A Cohen (ed.). Urban ethnicity. London: Tavistock.

Solossa, Jacobus Perviddya. (2005). Otonomi khusus Papua: mengangkat martabat rakyat Papua di dalam NKRI. Jakarta: Pustaka Sinar Harapan.

Sen, Amartya. (2007). Kekerasan dan ilusi tentang identitas, Tangerang: Marjin Kiri.

Tambunan, Edwin Martua Bangun. (2004). Nasionalisme etnik. Kashmir dan Quebec. Semarang: Intra Pustaka Utama. 
Vincent, Andrew. (2002). Nationalism and particularity. Cambridge: Cambridge University Press.

Widjojo, Muridan. (2007). 'Nasionalisme dan Etnisitas'. In Firman Noor (ed.). Nasionalisme, demokratisasi dan identitas primordialisme. Jakarta: Lembaga Ilmu Pengetahuan Indonesia, Pusat Penelitian Politik.

\section{Other sources}

Tempo, 6 March 2005.

www.cgi2you.com/members/message/mega/00122.shtml

www.kongresbudpar.go.id 